\title{
Pengaruh Pembelajaran Kewirausahaan Terhadap Motivasi Kewirausahaan
}

\author{
Zainul Muchlas \\ Institut ASIA, Malang \\ Email : zainul.muchlas@asia.ac.id
}

\begin{abstract}
This study aims to give consideration to the decision makers in developing entrepreneurship learning curriculum that can increase student motivation to make entrepreneurship as a career choice. The research was conducted in a Quasi Experiment by comparing entrepreneurial learning that can increase student motivation with high pull factors for entrepreneurship. Entrepreneurship learning methods are expected to encourage students with high pull factors to choose a career as an entrepreneur to alleviate undergraduate / educated unemployment in Indonesia. The learning groups that were compared consisted of Groups $A, B, C$, $D$ with different learning treatments. Findings This study shows that groups of students with high pull factors who obtain entrepreneurial learning have a significant increase in entrepreneurial motivation between before and after entrepreneurial learning. The highest increase in entrepreneurship motivation is group $C$ and group $D$ has the highest increase.
\end{abstract}

Keywords: Entrepreneurship learning, entrepreneurship motivation, learning methods.

\section{Pendahuluan}

Untuk menumbuhkembangkan jiwa kewirausahaan dan meningkatkan aktivitas kewirausahaan agar para lulusan perguruan tinggi lebih menjadi pencipta lapangan kerja dari pada pencari kerja, maka diperlukan suatu usaha nyata. Departemen Pendidikan Nasional telah mengembangkan berbagai kebijakan dan program untuk mendukung terciptanya lulusan perguruan tinggi yang lebih siap bekerja dan menciptakan pekerjaan. Misalnya, program hibah kuliah kewirausahaan bagi perguruan tinggi yang menyelenggarakan diberikan anggaran, yang dikompetisikan setiap tahun.

Untuk meningkatkan relevansi output perguruan tinggi dengan lapangan kerja diperlukan perangkat program percepatan pengembangan budaya kewirausahaan di perguruan tinggi. Program itu dilaksanakan untuk 
menumbuhkembangkan jiwa wirausaha para mahasiswa dan staf pengajar yang diharapkan bisa menjadi wahana pengintegrasiaan secara sinergi antara penguasaan sains dan teknologi dengan jiwa wirausaha (DP2M Dikti, 2006). Dengan tumbuh kembangnya budaya wirausaha di perguruan tinggi, maka hasil penelitian dan pengembangan selain bernilai akademik, diharapkan bisa mempunyai nilai tambah bagi kemandirian perekonomian bangsa dan peningkatan kesejahteraan masyarakatnya.

Pengembangan pembelajaran dan perangkat kompetensi lulusan perguruan tinggi merupakan suatu upaya untuk meningkatkan daya saing output di pasar kerja. Pakar Kewirausahaan Suharsono berpendapat bahwa salah satu di antara banyak metode yang dapat ditempuh adalah mengaitkan kompetensi utama dengan program pengembangan budaya kewirausahaan. Dalam kaitan dengan proses pembudayaan profesi wirausaha di perguruan tinggi, kebijakan dan program penguatan kelembagaan yang mendorong peningkatan aktivitas berwirausaha dan percepatan pertumbuhan wirausaha-wirausaha baru dengan basis IPTEKS sangat diperlukan.

Kecilnya minat berwirausaha di kalangan lulusan perguruan tinggi sangat disayangkan. Harusnya, melihat kenyataan bahwa lapangan kerja yang ada tidak memungkinkan untuk menyerap seluruh lulusan perguruan tinggi di Indonesia, para lulusan perguruan tinggi mulai memilih berwirausaha sebagai pilihan karirnya. Upaya untuk mendorong hal ini mulai terlihat dilakukan oleh kalangan institusi pendidikan, termasuk perguruan tinggi. Kurikulum yang telah memasukkan pelajaran atau mata kuliah kewirausahaan telah marak. Namun demikian, hasilnya masih belum terlihat. Para lulusan perguruan tinggi masih saja enggan untuk langsung terjun sebagai wirausahawan, dibuktikan dengan angka pengangguran terdidik yang ternyata malah makin meningkat.

Menurut pengamat pendidikan, Darmaningtyas menyebutkan bahwa ada kecenderungan, semakin tinggi tingkat pendidikan semakin besar keinginan mendapat pekerjaan yang aman. Mereka tak berani ambil pekerjaan berisiko seperti berwirausaha. Pilihan status pekerjaan utama para lulusan perguruan tinggi adalah sebagai karyawan atau buruh, dalam artian bekerja pada orang lain atau 
instansi atau perusahaan secara tetap dengan menerima upah atau gaji rutin. Hasil Sakernas semester pertama 2007 menunjukkan tiga dari empat lulusan perguruan tinggi memilih status tersebut. Hanya sedikit (5 persen) yang memiliki jiwa kewirausahaan, yaitu yang membuka usaha dengan mempekerjakan buruh atau karyawan yang dibayar tetap.

Kewirausahaan erat kaitannya dengan kondisi kejiwaan dan sifat dasar seseorang. Jika sifat-sifat dasar wirausaha telah melekat kuat dalam diri seseorang, dan mengapikasikannya dalam kebidupan nyata, maka kemungkinan besar mereka dapat menjadi wirausaha berhasil di kemudian hari.

Penelitian ini berupaya membandingkan pembelajaran kewirausahaan yang bisa meningkatkan motivasi mahasiswa untuk bekerja / berkarir menjadi wirausaha. Metode pembelajaran kewirausahaan diharapkan dapat mendorong pilihan karir berwirausaha pada mahasiswa guna mengentaskan pengangguran terdidik di Indonesia.

Pemilihan penelitian ini dilakukan di Kondisi di PTS Malang karena pada perguruan tinggi ini telah sekitar 5 tahun terakhir memasukkan mata kuliah kewirausahaan sebagai Kurikulum inti Unggulan, perlu rumusan yang jelas agar bisa menghasilkan mahasiswa yang mau berkarir di dunia wirausaha.

Kebutuhan akan wirausahawan yang memiliki kemampuan dan skill yang bagus untuk memajukan industri hingga kini belum ada rujukan metode pemeblajaran yang mampu mengubah motivasi mahasiswa dari tidak menjadi wirausaha menjadi ingin berkarir sebagai wirausaha. Yang ada hanya kurikulum kewirausahaan yang orientasinya masih berkutat pada Ilmu kewirausahaan /kewirausahaan bukan pada mengubah motivasi mahasiswa agar bersedia menjadi wirausahawan atau pencipta lapangan kerja . Apalagi saat ini negeri kita sedang menggalakkan peningkatan jumlah wirausahawan kalau bisa mencapai lebih dari $2 \%$ penduduk Indonesia.

Berdasarkan latar belakang masalah tersebut diatas, maka perumusan masalah dalam penelitian adalah "Bagaimanakah membandingkan materi pembelajaran kewirausahaan yang bisa meningkatkan motivasi mahasiswa untuk bekerja / berkarir menjadi wirausaha?" Untuk mendukung studi empiris tersebut di 
atas, masalah penelitian dikembangkan menjadi beberapa pertanyaan pokok yang diajukan antara lain, (1) Apakah Pemberian materi kuliah kewirausahaan dapat meningkatkan motivasi berwirausaha mahasiswa dengan faktor penarik/ pull yang tinggi. (2) Apakah setelah mengikuti perkuliahan kewirausahaan motivasi berwirausaha mahasiswa dengan faktor penarik/ pull yang tinggi pada keempat perlakuan adalah berbeda. (3) Apakah ada perbedaan perubahan motivasi berwirausaha yang signifikan pada kelompok B dibandingkan dengan kelompok A. (4) Apakah ada perbedaan perubahan motivasi berwirausaha yang signifikan pada kelompok C dibandingkan dengan kelompok A. (5) Apakah ada perbedaan perubahan motivasi berwirausaha yang signifikan pada kelompok D dibandingkan dengan kelompok A. (6) Apakah ada perbedaan perubahan motivasi berwirausaha yang signifikan pada kelompok C dibandingkan dengan kelompok B. (7) Apakah ada perbedaan perubahan motivasi berwirausaha yang signifikan pada kelompok D dibandingkan dengan kelompok B. (8) Apakah ada perbedaan perubahan motivasi berwirausaha yang signifikan pada kelompok D dibandingkan dengan kelompok C.

\section{Hipotesis Penelitian}

Dalam penelitian diduga hasil yang akan diperoleh bisa dirumuskan antara lain: (1) Pemberian materi kuliah kewirausahaan dapat meningkatkan motivasi berwirausaha mahasiswa dengan faktor penarik/ pull yang tinggi. (2) Setelah mengikuti perkuliahan kewirausahaan, motivasi berwirausaha mahasiswa dengan faktor penarik/ pull yang tinggi pada keempat perlakuan adalah berbeda. (3) Ada perbedaan perubahan motivasi berwirausaha yang signifikan pada kelompok B dibandingkan dengan kelompok A . (4) Ada perbedaan perubahan motivasi berwirausaha yang signifikan pada kelompok $\mathrm{C}$ dibandingkan dengan kelompok A . (5) Ada perbedaan perubahan motivasi berwirausaha yang signifikan pada kelompok D dibandingkan dengan kelompok A. (6) Ada perbedaan perubahan motivasi berwirausaha yang signifikan pada kelompok $\mathrm{C}$ dibandingkan dengan kelompok B. (7) Ada perbedaan perubahan motivasi berwirausaha yang signifikan pada kelompok D dibandingkan dengan kelompok B. 


\section{Tinjauan Pustaka}

Motivasi sukses berhubungan dengan prestasi sosial atau imbalan ekonomi, dsb. Motivasi sukses dapat diwujudkan dalam bentuk kenaikan pangkat/promosi sebagai tanda prestasi, dan imbalan lebih yang dapat menjawab kebutuhan ekonomi serta penghargaan sosial lain.

Motivasi diri atau "self motivation" adalah upaya membangunkan semangat diri dengan sugesti diri secara positif. Sugesti diri secara positif dapat dikembangkan dengan metode terus-menerus mengembangkan sikap positif, pilihan-pilihan positif, dan keputusan positif yang membangun diri dan orang lain. Motivasi diri bertujuan menjaga kestabilan sikap serta tekad untuk terus maju dan berprestasi.

Naomi (2000) melakukan penelitian untuk mengevaluasi program pembelajaran Student Placements for Entrepreneurs in Education (SPEED) yang berbasis experiential learning terhadap niat siswa untuk memulai usaha sebagai pilihan karir. Hasil peneltiian menemukan bahwa program pembelajaran Student Placements for Entrepreneurs in Education (SPEED) yang berbasis experiential learning memberikan siswa untuk memperoleh pengalaman, kepercayaan dan pengetahuan terhadap suatu bisnis atau menggunakan pengalaman baru yang mereka berhasil temukan untuk memulai usaha sebagai pilihan karir setelah meraka lulus.

Fregetto, E. (2002) meneliti efektivitas dari simulasi bisnis pada 3 kelas kewirausahaan di Universitas Illinois Chicago. Penelitian ini menemukan efektivitas simulasi bisnis untuk pengajaran kewirausahaan. Penggunaan metoda experiential learning dalam pendidikan kewirausahaan menjadi hal penting, sebab pendidik mata kuliah kewirausahaan menyukai belajar experiential agar para siswa mereka mengenali kekurangan kelas kewirausahaan berbasis ceramah (lecture-based). Hasil penelitian menemukan bahwa simulasi bisnis adalah merupakan hal positif yang dapat meningkatkan pengalaman belajar para siswa.

Lee dan Wong (2003) melakukan penelitian tentang pengaruh faktor lingkungan sebagai faktor penarik berwirausaha. Faktor lingkungan dilihat dari 
faktor dalam aspek demografis (umur, gender, pendapatan, pendidikan) dan psikologis (need for achievment, locus of control, pengambilan resiko dan kebebasan).

Hasil yang didapat dalam penelitian ini adalah: adanya hubungan antara faktor umur, politeknik, pengalaman kerja dan pendidikan terhadap kesiapan untuk memulai usaha baru (berwirasuaha sebagai pilihan karir). Namun penelitian ini tidak menemukan pengaruh faktor need for achievment, locus of control, pengambilan resiko dan kebebasan serta faktor lingkungan lainnya (seperti: umur, kondisi sosial ekonomi) terhadap kesiapan untuk memulai usaha baru. Zimmerer dan Scarborough (2005) yang mendefinisikannya entrepreneur sbb: An Entrepreneur is one who creates a new business in face of risk and uncertainty for the purpose of achieving profit and growth by identifying significant opportunities and assembling the necessary resources to capitalize on them. Seorang entrepreneur /wirausahawan adalah orang yang berani menanggung resiko atas bisnis yang dia tekuni.

Geoffrey G.Meredith et al (2002) mengemukakan daftar ciri-ciri dan sifat-sifat sebagai profil wirausaha sebagaimana tersusun dalam Tabel 1.

Tabel 1: Ciri-ciri dan Watak Wirausaha

\begin{tabular}{|l|l|}
\hline Ciri-ciri & Watak \\
\hline Percaya Diri & $\begin{array}{l}\text { Keyakinan, ketidaktergantungan, individualitas, } \\
\text { optimis. }\end{array}$ \\
\hline $\begin{array}{l}\text { Berorintasikan tugas } \\
\text { dan hasil }\end{array}$ & $\begin{array}{l}\text { Kebutuhan akan prestasi, berorientasi laba, } \\
\text { ketekunan,ketabahan, tekad kerja keras, mempunyai } \\
\text { dorongan kuat, energetic, dan inisiatif. }\end{array}$ \\
\hline Pengambil Risiko & Kemampuan mengambil risiko, suka pada tantangan. \\
\hline Kepemimpinan & $\begin{array}{l}\text { Bertingkah laku sebagai pemimpin, dapat bergaul } \\
\text { dengan orang lain, menanggapi saran-saran dan kritik. }\end{array}$ \\
\hline Keorisinilan & Inovatif dan kreatif, fleksibel, mengetahui banyak. \\
\hline Orientasi masa depan & Pandangan jauh ke depan \\
\hline
\end{tabular}

Sumber: Geoffrey G.Meredith at al, 2002

Cooper \& Dunkelberg (1984) menjelaskan teori kewirausahaan dengan mempertimbangkan berbagai faktor yang ikut berperan dalam pengambilan keputusan usahawan. Faktor tersebut antara lain pengaruh keturunan, inkubasi 
organisasi serta faktor lingkungan. Usahawan dengan berbagai latar belakangnya dapat berpengaruh terhadap motivasi, persepsi, pengetahuan dan keterampilannya. Organisasi dimana pengusaha telah bekerja sebelumnya, karakteristiknya dapat mempengaruhi penempatan dan sifat alami perusahaan baru seperti halnya pada pengalihan perusahaan ke perusahaan lainnya.

Sosiolog dan psikolog menjelaskan kewirausahaan sebagai variabel independen yang membantu menjelaskan dari karakteristik sosial dan psikologi (Winkel:1991). Variabel kewirausahaan dalam konteks interdisipliner dipahami sebagai growth entrepreneurship dalam menganalisis kewirausahaan dalam bidang industri. Dimensi growth entrepreneurship dihubungkan dengan prime motivation yang terdiri dari oneself / Close friend, relative, a goodfather. Ambition terdiri dari Starting a ventura, Desire to earn more money, Dissatisfaction terdiri dari job, unemployment, compelling previous experience in the same field, facilitating terdiri dari favourable good policy, constitute the classic, opportunity terdiri dari market access to trade information (Martin, 2004).

Dalam menguraikan konsep kewirausahaan Winkel (1991) mengusulkan tiga faktor yang berpengaruh yaitu economic faktor seperti perangsang pasar (market incentives) dan ketersediaan modal (availability of capital), non economic faktor seperti gerakan sosial (social mobility), ideolgi (ideology), dan budaya (culture) dan lain sebagainya serta psychological faktor seperti needachievement, withdrawal status, dan lain sebagainya.

Lambing \& Kuehl (2003) dan Gilad dan Levine (1986) mengklasifikasikan beberapa faktor yang menyebabkan seseorang menjadi wirausahawan. Faktorfaktor tersebut adalah: Individu, Budaya, Keadaan Masyarakat dan Kombinasi dari berbagai faktor. Dalam tinjauan individu, seorang wirausahawan mempunyai kepribadian khusus yang membedakan antara mereka dengan orang lain yang memilih untuk tidak menjadi wirausahawan dan hal ini tidak dapat diajarkan. Hal ini didukung pula oleh Zimmerer \& Scarborough (1998) yang mencatat sifat-sifat yang berkaitan dengan keberhasilan usaha dan mengajukan sebuah pandangan tentang tipe kepribadian wirausaha yang dikaitkan dengan keberhasilan mengelola usaha. Dalam tinjauan Budaya, pengaruh budaya 
dengan trait kepribadian dapat saling tumpang tindih antara yang satu dengan yang lainnya. Kombinasi dari berbagai faktor melihat bahwa seseorang memutuskan untuk menjadi wirausaha karena ketiga faktor yang sudah disebutkan diatas yang saling mempengaruhi satu sama lain (Lambing \& Kuehl, 2003). Selain faktor-faktor diatas ada juga suatu kondisi yang mendorong seseorang untuk menjadi wirausahawan. Menurut Ward (1974) kondisi dimana seseorang dibesarkan dalam lingkungan keluarga dengan tradisi wirausaha dapat menjadi faktor yang mendorong seseorang untuk menjadi wirausahawan. Ward (1974) mengasumsikan bahwa seorang anak yang secara turun temurun menjadi wirausahawan akan berkembang menjadi seorang wirausahawan juga. Beberapa penelitian (Keeble et al., 1992; Orhan and Scott, 2001) mengindikasi bahwa kebanyakan individu menjadi wirausaha terutama disebabkan "pull" factors, daripada "push" factors.

Teori yang paling sering dipakai dalam memperkirakan suatu dorongan perilaku adalah teori reasoned action (Ajzen and Fishbein, 1980; Fishbein and Ajzen, 1975) dan teori planned behavior (Ajzen, 1988, 1991 Segal, Borgia and Schoenfeld, 2005). Teori planned behavior (TPB) adalah kelanjutan dari teori reasoned action (TRA) yang memasukkan pengukuran dalam control belief dan perceived behavioral control.

Segal, Borgia dan Schoenfeld (2005) menyatakan bahwa hampir sama dengan metode Ajzen di atas, metode kejadian kewirausahaan dari Shapero (1982) pun memiliki dua faktor utama, yaitu perceived credibility (perceived feasibility) dan perceived desirability. Shapero and Sokol (1982) mengkonsepkan perceived desirability sebagai ketertarikan personal untuk memulai bisnis. Adapun perceived feasibility dikonsepkan sebagai pengukuran yang bersifat persepsi atas kapabilitas seseorang terkait menciptakan usaha baru. Sebagai tambahan, Shapero juga menambahkan variabel ketiga, propensity to act yang konsepnya sangat dekat dengan lokus kendali (locus of control). Shapero and Sokol (1982) and Krueger (1993) sebagaimana dikutip Segal, Borgia dan Schoenfeld (2005) berpendapat bahwa perceived desirability, perceived feasibility, and propensity to act berhubungan dengan 
motivasi untuk berwirausaha. Metode dari Azjen and Shapero juga mempertimbangkan efikasi diri (self-efficacy), pengganti dari feasibility, sebagai prediktor yang penting. Chen et al. (1998) sebagaimana dikutip Segal, Borgia dan Schoenfeld (2005), menemukan bahwa entrepreneurial self-efficacy adalah pengukuran yang andal untuk membedakan wirausaha dan bukan wirausaha.

Pengaruh keluarga, pendidikan dan pengalaman kerja pertama adalah faktor penting dalam pengembangan karir (Segal, Borgia, \& Schoenfeld, 2005). Orang tua memberikan dampak kuat pada pemilihan karir, penelitian menunjukkan para wirausaha biasanya memiliki orang tua yang juga seorang wirausaha (Farzier \& Niehm, 2008). Pendidikan dan pengalaman kerja dapat mempengaruhi pilihan karir dengan mengenalkan ide-ide baru, membangun keterampilan yang diperlukan dan menyediakan akses pada role metode (Farzier \& Niehm, 2008).

Beberapa studi literatur kualitatif dan kuantitatif banyak menemukan efektivitas experiential learning dalam berbagai situasi, dan telah terbukti dapat digunakan sebagai kerangka untuk pengembangan metoda dan kurikulum learning-centred yang baru (Hickcox, 1991; Iliff, 1994). Experiential learning telah digunakan dalam inter-disciplinary dan multi-disciplinary (Kolb, Boyatzis\& Mainemelis, 2001). Experiential learning sebagai alat penghubung pendidikan dan manajemen.

Kewirausahaan dilihat sebagai sesuatu yang bisa diajar dan beberapa hal dilihat sebagai karakteristik personal sebagai pembawaan sejak lahir (Kuratko, 2005). Pendidikan kewirausahaan tidak sama dengan kebanyakan aspek pendidikan manajemen. Pendidikan kewirausahaan harus dimulai dengan bekerja pada berbagai situasi melalui banyak pertentangan. Timmons \& Spinelli (2004) berpendapat bahwa kewirausahaan adalah tak beraturan, tidak linier, dan tak dapat diramalkan. Mereka berpendapat bahwa pendidikan kewirausahaan yang efektif harus mengakibatkan pengembangan ketrampilan dan kemampuan yang dapat menciptakan tindakan untuk dapat keluar dari kerancuan, kekacauan, dan ketidak-pastian. 
Seperti dicatat oleh Bandura (1991), pengalaman pribadi menjadi faktor yang paling utama yang mempengaruhi pengembangan self-efficacy. Hamer (2000) mencatat bahwa hal penting dalam penerapan pengajaran kewirausahaan berkaitan tentang metoda yang berdasar praktek (field-based) ( seperti melalui pelatihan suatu keahlian) dan sedikit didukung metoda pengajaran kelas (classroom-based) ( seperti: permainan peran dan simulasi). Teknik pembelajaran experiential adalah teknik yang modifikasi format kuliah melalui ceramah sebagai metode tradisional dengan siswa bekerja melalui pengalaman yang tersusun dalam kelompok kecil (Gaidis, Andrews, \& Summer, 1991) untuk melaksanakan riset pemasaran nyata (Churchill, 1986) sebelum magang full-time sebagai praktek usahawan (Aronsson, 2004).

Beberapa studi empiris menemukan hal positif bahwa kewirausahaan dapat diajarkan (seperti dilakukan oleh: et. al, 2006; Lepoutre et. al, 2005; Naomi ( 2000; Ahmad et. al, 2010; Pihie , 2009; Schreier, 1984; Douglas \& Shepherd, 2002; Rasmussena dan Sørheimb, 2006; Fregetto, 2002; Atherton, 2007). Demikian juga hasil penelitian Mcmullan \& Gillin (1998) dan Vesper ( 1994) yang menemukan bahwa kewirausahaan dapat diajar. Gorman\& Hanlon ( 1997) melakukan literatur review beberapa penelitian dalam jangka waktu 10-tahun berkaitan dengan pendidikan kewirausahaan. Hal ini berbeda dengan manajemen kursus/pelatihan dimana selalui menemukan hasil positif (Hostager \& Decker, 1999). Riset baru-baru ini yang dilakukan oleh Raichaudhuri (2005) menemukan bahwa lebih dari 50 persen para mahasiswa yang mengambil kelas kewirausahaan di Universitas Harvard telah memulai usaha sendiri. Donckels\& Miettinen (1997) berpendapat bahwa peran pendidikan kewirausahaan yang utama adalah menaikkan penerimaan dan kesadaran siswa untuk melakukan spekulasi dengan mengambil resiko melalui berkarir sebagai wirausaha.

Wang \& Wong (2004) dalam penelitian di Singapura, menemukan bahwa sebelum mengenal pendidikan kewirausahaan, mahasiswa mempunyai persepsi dan pengetahuan yang tinggi tentang kewirausahaan. Setelah mengambil matakuliah kewirausahaan persepsi mahasiswa mengalami peningkatan. Lee\& Wong ( 2003) dalam studinya menemukan bahwa pendidikan kewirausahaan 
pada perguruan tinggi mempunyai hubungan langsung dalam membentuk sikap siswa dalam mengambil resiko untuk pendirian usaha baru. Penelitian Lee \& Wong menduga bahwa persepsi usahawan semakin positif melalui pendidikan kewirausahaan, namun juga dipengaruhi oleh faktor lingkungan eksternal dan dukungan kewirausahaan oleh pemerintah. Lebih dari itu, pemerintah Singapura banyak melakukan dukungan agar mahasiswa setelah lulus dapat memulai usaha baru.

Niat berwirausaha (entrepreneurial intention) dapat dilihat sebagai minat untuk menciptakan suatu organisasi baru ( Katz\& Gartner, 1988) atau sebagai perilaku mengambil resiko untuk memulai suatu bisnis baru (Krueger, 2000). Niat (intention) dapat dilihat seperti penyebab suatu tindakan dan yang lebih tinggi adalah melaksanakan tindakan, yang lebih tinggi lagi adalah kemungkinan dalam melibatkan aksi/tindakan (Chandrashekaran, McNeilly, Russ,\& Marinova, 2000). Beberapa studi terdahulu telah menemukan suatu mata rantai yang kuat antara niat dan perilaku dalam kewirausahaan dalam berbagai situasi ( Douglas\& Gembala, 2002; Sheppard, Hartwick,\& Warshaw, 1988).

Menurut Solomon dan Fernald (1991) serta Hisrich dan Peters (2002) sebagaimana dikutip Bell (2008), pendidikan kewirausahaan tradisional memfokuskan pada penyusunan rencana bisnis, bagaimana mendapatkan pembiayaan, proses pengembangan usaha dan manajemen usaha kecil. Pendidikan tersebut juga memberikan pengetahuan mengenai prinsip-prinsip kewirausahaan dan keterampilan teknis bagaimana menjalankan bisnis. Namun demikian, peserta didik yang mengetahui prinsip-prinsip kewirausahaan dan pengelolaan bisnis tersebut belum tentu menjadi wirausaha yang sukses (Solomon and Fernald dalam Bell, 2008).

Mereka perlu dibekali dengan berbagai atribut, keterampilan dan perilaku yang dapat meningkatkan kemampuan kewirausahaan mereka. Artinya mata kuliah kewirausahaan perlu dirancang secara khusus untuk dapat mengembangkan karakteristik kewirausahaan, seperti kreativitas, pengambilan keputusan, kepemimpinan, jejaring sosial, manajemen waktu, kerjasama tim, dll (Brockhaus; Rae, dalam Bell, 2008). Untuk itu diperlukan 
perubahan sistem pendidikan kewirausahaan yang tadinya difokuskan pada orientasi pengendalian fungsional seperti, keuangan, pemasaran, sumber daya manusia dan operasi (Meyer dalam Bell, 2008) menjadi fokus pada mengembangkan jiwa kewirausahaan pada peserta didik. Sehingga tantangannya adalah bagaimana sistem pembelajaran yang dapat mengembangkan diri peserta didik mereka dalam hal keterampilan, atribut dan sekaligus karakteristik perilaku seorang wirausaha (Gibb, dalam Bell, 2008).

Pembelajaran sebagai suatu sistem terdiri atas komponen-komponen yang satu sama lain saling bekerjasama secara harmonis untuk mencapai tujuan yang diinginkan. Komponen komponen tersebut adalah: (1) Raw input yaitu siswa / mahasiswa, di dalamnya ada unsur fisik maupun psikis. (2) Instrumental input, yaitu terdiri atas guru/dosen, sarana dan prasarana pembelajaran, kurikulum, pendekatan, strategi, metode-metode mengajar, alat-alat dan evaluasi belajar. (3) Environmental input, yaitu lingkungan tempat terjadinya proses pembelajaran. (4) Proses pembelajaran, yaitu peristiwa terjadinya belajar mengajar, dimana semua komponen berperan melakukan fungsinya dalam rangka mencapai tujuan yang diinginkan. (5) Output, yaitu luaran atau lulusan atau kondisi siswa yang diharapkan setelah melaksanakan pembelajaran tersebut (Nasution, 1992)

Menurut Hamalik (1999) pembelajaran adalah suatu kombinasi yang tersusun meliputi unsur-unsur manusiawi, material, fasilitas, perlengkapan, dan prosedur yang saling mempengaruhi mencapai tujuan pembelajaran. Unsur manusia terdiri atas siswa dan guru, dan tenaga lainnya seperti tenaga non guru. Material meliputi buku-buku pelajaran papan tulis, kapur, fotografi, slide, gambargambar dan lain sebagainya. Prosedur pembelajaran meliputi jadwal pelajaran, metode penyampaian pelajaran, praktek, prosedur belajar, ujian dan sebagainya. Prestasi belajar adalah hasil yang diperoleh mahasiswa dari kegiatan belajar. Prestasi belajar biasanya dinyatakan dalam bentuk simbol, angkaangka, huruf, atau kalimat atau pernyataan verbal. Menurut Gunarsa (1989:75) prestasi belajar adalah hasil maksimum yang dicapai oleh seseorang setelah melakukan 
usaha belajar.

Menurut laporan dari Global Entrepreneurship Monitor (GEM) terdapat suatu korelasi tinggi antara pendidikan, termasuk dalam hal ini adalah pembelajaran kewirausahaan dengan kepercayaan dan motivasi individu untuk terlibat dalam aktivitas kewirausahaan (GEM 2001; GEM 2003). Dalam hal ini, pendidikan turut mendukung dan berperan penting dalam pengembangan kewirausahaan di seluruh dunia. Oleh karena itu, berbagai pihak mendorong lulusan universitas untuk belajar kewirausahaan dan mendorong mereka untuk dilibatkan di dalam perusahaan.

Menurut Garavan dan Barra ( 1994) wirausahawan dan innovator memiliki tiga karakteristik utama, yang terdiri dari: pengetahuan, sikap dan ketrampilan. Pengetahuan adalah seperti pengetahuan industri, produk, teknik atau proses (Marvel and Lumpkin, 2007). Ketrampilan adalah seperti ketrampilan networking, ketrampilan manajemen, ketrampilan keuangan, ketrampilan komunikasi, ketrampilan pengambilan keputusan, ketrampilan personal (seperti ketekunan dan kerja keras). Menurut Hisrich dan Peter (1998) ketiganya sama pentingnya bagi wirausahawan. Sikap adalah sikap terhadap pengambilan resiko (risk-taking), seperti halnya kekuatan psycho-social individu dan kontek budaya, mempengaruhi perilaku bersifat wirausahawan (Ferreira dan Raposo, 2008). Sebagai konsekwensi, Pembelajaran kewirausahaan perlu memusatkan perhatian pada: (a) Penyebarluasan pengetahuan tentang manfaat kewirausahaan, (b) Memperoleh alat untuk menganalisis dan membaca lingkungan bisnis dalam mengembangkan perencanaan bisnis, (c) Mengembangkan ketrampilan wirausahawan, pengelolan dan bakat, (d) Motivasi individu untuk mendukung kewirausahaan, (e) Stimulasi Pemikiran kreatif, (f) Mengembangkan sikap yang positif dan keinginan untuk berubah, (g) Memberi harapan dan mendukung wirausaha baru (Garavan dan Barra, 1994; Ferrueira dan Raposo, 2008).

Uraian di atas menggambarkan disiplin multiaspek pendidikan kewirausahaan, komitmennya untuk mempromosikan secara kreatif dan berpikir crossfunctional melalui pendekatan holistik dan integratif diperlukan terhadap 
pencapaian tujuan dari pembelajaran kewirausahaan ( Tan dan $\mathrm{Ng}$, 2006). Lebih dari itu, pembelajaran kewirausahaan diarahkan pada individu dari berbagai disiplin: ilmuwan, teknologi dan perencana spesialis, para profesional dalam industri kreatif, para manajer dalam organisasi kecil maupun besar.

Pembelajaran Kewirausahaan di Indonesia disusun oleh Direktorat Jendral Pendidikan Tinggi (Ditjen Dikti). Berdasarkan tujuan yang ingin dicapai, Program Pengembangan Budaya Kewirausahaan di Perguruan Tinggi dirancang meliputi 5 (lima) kegiatan saling terkait sebagai wahana diwujudkannya wirausahawan lulusan perguruan tinggi, yaitu: Kuliah Kewirausahaan (KWU), Magang Kewirausahaan (MKU), Kuliah Kerja Usaha (KKU), Konsultasi Bisnis dan Penempatan Kerja (KBPK), dan Inkubator Wirausaha Baru (INWUB).

Tidak semua mahasiswa harus memulai kegiatan belajar kewirausahaan dengan mengikuti KWU. Setiap mahasiswa dapat menentukan akan memulai dari wahana yang sesuai dengan kemampuan, pengalaman dan peluang yang tersedia. Namun demikian, secara ideal seluruh wahana hendaknya dilaksanakan secara terpadu dan berkesinambungan dengan mengikuti bagan alir seperti tersaji dalam gambar berikut:

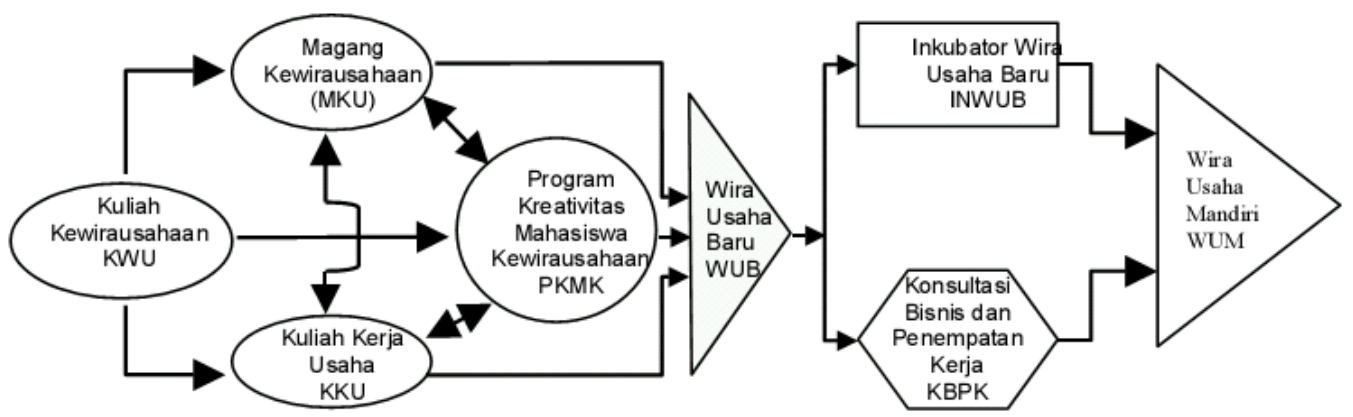

Gambar 1. Bagan Alir Keterkaitan Berbagai Kegiatan Program Pengembangan Budaya Kewirausahaan Mahasiswa di Indonesia

Pembelajaran Kewirausahaan di Portsmouth University diantaranya dikenal dengan "Post- Enterprise Boot Camp 2007” bertujuan membawa siswa untuk mencoba usaha baru. Merupakan kerjasama dari Universitas Portsmouth, Southampton, Winchester dan Southampton Solent. Kegiatan tersebut menyajikan suatu pengalaman, tantangan dan peluang Pembelajaran yang 
intensif yang memberi siswa kesempatan untuk belajar ketrampilan dengan mencoba usaha baru mereka. Mereka juga mempelajari ketrampilan baru melalui suatu campuran lokasi dan lingkungan pekerjaan, aktivitas kelompok, networking dan belajar peristiwa. Peristiwa kejadian disediakan untuk memberikan masukan eksternal untuk membantu menyediakan suatu pengertian yang mendalam dan terukur yang biasa terjadi dalam hidup seharihari ketika mereka menjalankan perusahaan.

\section{Kerangka Konsep}

\section{Faktor Penarik (pull):}

kesempatan untuk membuka usaha baru, keterbatasan lapangan pekerjaan saat ini, ketidak lenturan jam kerja serta keyakinan berwirausaha dapat memberikan kemakmuran

\section{Methode Pembelajaran \\ Kewirausaahan: \\ Teori+Penugasan, Cerita \\ Tokoh, atau Pemutaran \\ Video atau \\ Brainstorming}

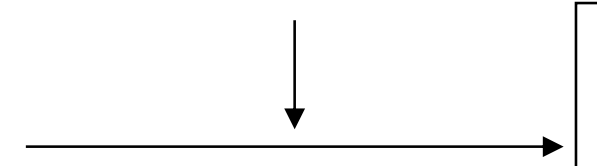

Motivasi mahasiswa dalam bekerja/berkarir menjadi wirausaha:

tingkat kemenarikan karir (career attractiveness), tingkat kelayakan (feasibility) dan keyakinan atas efikasi diri (self-efficay beliefs)

Gambar 2. Kerangka konsep Penelitian

\section{Metode Penelitian}

\section{Desain Penelitian}

Penelitian dilakukan pada kuliah kewirausahaan di Perguruan Tinggi Swasta Malang. Subyek penelitian adalah mahasiswa yang sedang mengambil mata kuliah kewirausahaan pada semester II Tahun kuliah 2018/2019. Waktu penelitian dibatasi selama 1 (satu) semester atau 15 Minggu pada semester genap tahun pelajaran 
2018/2019, terhitung sejak bulan April sampai dengan Juli 2019.

Desain penelitian ini menggunakan desain eksperimen pretest-postest control group design yakni desain penelitian eksperimen dengan membagi peserta kuliah menjadi 4 group kelompok eksperimen dan 1 kelompok pembanding (control), yaitu: (a) Kelompok A hanya mendapatkan teori kewirausahaan dan Penugasan selama perkuliahan. (b) Kelompok B mendapatkan teori kewirausahaan ditambah penugasan dan cerita tokoh sukses berwirausaha. (c) Kelompok C mendapatkan teori kewirausahaan ditambah penugasan dan pemutaran video tokoh success berwirausaha. (d) Kelompok D mendapatkan teori kewirausahaan ditambah penugasan dan brainstorming berbagai pemikiran berkarir menjadi wirausaha. (d) Kelompok $\mathrm{K}$ adalah kontrol yang tidak mendapatkan tretmen (kuliah kewirausahaan).

Kelompok kontrol dan kelompok eksperimen yang didahului dengan pretest dan diakhiri postest. Kelompok kontrol pretes-postes untuk menguji perbedaan pengaruh suatu perlakuan/tretmen yang diujicobakan (Sugiyono,2008: 76).

Dalam penelitian ini terdapat dua kelompok, yaitu kelompok yang diberi perlakuan / treatmen sebagai kelompok eksperimen dan kelompok yang tidak diberikan treatmen materi kuliah kewirausahaan sebagai kelompok kontrol. Untuk menentukan kelompok eksperimen dipilih mahasiswa yang memprogram kuliah kewirausahaan dan kelompok kontrol dipilih mahasiswa yang tidak memprogram kuliah kewirausahaan. Untuk mengetahui bahwa kemampuan awal kedua kelompok eksperimen dan kelompok kontrol tersebut tidak berbeda secara signifikan (seimbang), sebelum pemberian perlakuan diadakan pretest.

Secara keseluruhan, tahapan penelitian adalah (1) Pembuatan instrumen dan uji coba-instrumen, (2) Melakukan pra-survey dan perijinan ke PTS Malang, (3) Mengadakan pertemuan koordinasi dengan dosen yang mengajar mata kuliah kewirausahaan di PTS Malang (4) Mengembangkan materi pembelajaran mata kuliah kewirausahaan untuk treatmen, (5) Melaksanakan pretest, Melaksanakan eksperimen pembelajaran mata kuliah kewirausahaan dengan treatmen, (7) Melaksanakan postest setelah eksperimen selesai, dan (8) Melakukan analisis data. 
Secara garis besar, kegiatan eksperimen ini meliputi: pertama mengadakan/pretest, kedua memberikan perlakuan eksperimen berupa pernberian pembelajaran berbasis pembelajaran mata kuliah kewirausahaan, ketiga memberikan postest . Secara rinci, masing-masing kegiatan tersebut dapat dijelaskan sebagai berikut:

a. Pretest (tes awal)

Pretest (tes awal) dilakukan secara tertulis pada 2 kelompok (kontrol dan eksperimen) sebelum kelompok eksperimen diberi perlakuan. Kelompok eksperimen juga diminta untuk mengisi angket sebelum diberi tretmen, untuk mengetahui motivasi mahasiswa untuk menjadi wirausaha sebagai pilihan karir. Kemudian Postest (tes akhir) untuk mengetahui perbedaan hasil belajar menggunakan pembelajaran Kewirausahaan. baik pada kelompok kontrol sebagai pembanding dan kelompok eksperimen.

b. Perlakuan (tretmen) metode pembelajaran Kewirausahaan

c. Setelah mendapatkan pretest kelompok eksperimen mendapatkan pembelajaran Kewirausahaan baik yang hanya bersifat teoritis saja maupun teoritis dan disertai motivasi, sedangkan kelompok kontrol tidak mendapatkan pembelajaran kewirausahaan baik secara teoritis maupun motivasi.

d. Postest (tes akhir)

Posttest (tes akhir) dilakukan terhadap kelompok sesudah kelompok eksperimen mendapatkan perlakuan/treatmen Selama 15 minggu, sedangkan kelompok kontrol juga dilakukan post test pada minggu ke 15.

\section{Hasil Dan Pembahasan}

Secara khusus analisis ini dilakukan terhadap 139 sampel mahasiswa yang tergolong memiliki faktor penarik tinggi. Hasil analisis kovarian dengan tujuan menguji adanya perbedaan motivasi berwirausaha pada kelima perlakuan disajikan pada Tabel berikut: 
Tabel 2

Ringkasan Hasil ANOVA Motivasi Berwirausaha Pada Kelompok Sampel Dengan Faktor Penarik Tinggi

\begin{tabular}{|l|r|r|r|r|r|}
\hline Source & $\begin{array}{r}\text { Type III Sum of } \\
\text { Squares }\end{array}$ & Df & Mean Square & \multicolumn{1}{c|}{ F } & \multicolumn{1}{c|}{ Sig. } \\
\hline Motivasiawal & 755.482 & 1 & 755.482 & 2.307 & .131 \\
Perlakuan & 6548.053 & 4 & 1637.013 & 4.998 & .001 \\
Error & 43561.889 & 133 & 327.533 & & \\
Corrected Total & 50923.281 & 138 & & & \\
\hline
\end{tabular}

Tabel 2 menunjukkan bahwa pada kelompok mahasiswa dengan faktor penarik tinggi, ada perbedaaan yang signifikan motivasi berusaha pada kelima kelompok perlakuan. Keputusan uji didasarkan pada nilai sebesar 4,998 menghasilkan $\mathrm{p}$-value $=0,002$ yang lebih kecil dari $\alpha=0,05$. Selanjutnya karakteristik perbedaaan kelima perlakuan diuji dengan uji beda nyata terkecil

Tabel 3.

Hasil Uji Beda Rata-rata Motivasi Berwirausaha Pada Kelompok Sampel Dengan Faktor Penarik Tinggi

\begin{tabular}{|l|c|c|c|c|c|c|}
\hline \multirow{2}{*}{ Perlakuan } & Rata-rata & \multicolumn{5}{|c|}{$p$-value hasil uji beda } \\
\cline { 3 - 7 } & & Kontrol & $\mathrm{A}$ & $\mathrm{B}$ & $\mathrm{C}$ & $\mathrm{D}$ \\
\hline Kontrol & $140.726^{\mathrm{a}}$ & - & $0.847 \mathrm{~ns}$ & $0.258 \mathrm{~ns}$ & $0.005 *$ & $0.000 *$ \\
$\mathrm{~A}$ & $141.783^{\mathrm{a}}$ & $0.847 \mathrm{~ns}$ & - & $0.435 \mathrm{~ns}$ & $0.029 \mathrm{~ns}$ & $0.004 *$ \\
$\mathrm{~B}$ & $146.443^{\mathrm{a}}$ & $0.258 \mathrm{~ns}$ & $0.435 \mathrm{~ns}$ & - & $0.098 \mathrm{~ns}$ & $0.030 *$ \\
$\mathrm{C}$ & $154.345^{\mathrm{a}}$ & $0.005 *$ & $0.029 *$ & $0.098 \mathrm{~ns}$ & - & $0.488 \mathrm{~ns}$ \\
$\mathrm{D}$ & $157.728^{\mathrm{a}}$ & $0.000 *$ & $0.004 *$ & $0.030 *$ & $0.488 \mathrm{~ns}$ & - \\
\hline
\end{tabular}

Keterangan :

ns $\quad$ : p-value $>0,05=$ kedua kelompok berbeda tidak signifikan

* $\quad$ : p-value $\leq 0,05=$ kedua kelompok berbeda signifikan

Karakteristik hasil uji beda motivasi berwirausaha kelima kelompok pada 139 sampel dengan faktor penarik tinggi dapat dijelaskan menjadi dua bagian yaitu perbedaan kelompok kontrol dengan perlakuan dan perbedaan antar kelompok perlakuan. Motivasi berwirausaha pada kelompok kontrol memberikan hasil uji beda rata-rata yang tidak signifikan pada perlakuan A, dan signfikan pada perlakuan B, C dan D. Sementara karakteristik perbedaaan di kelompok perlakuan dapat dijelaskan pada poin-poin ini antara lain (1) Pemberian materi tambahan akan 
meningkatkan motivasi berwirausaha (2) Motivasi berwirausaha pada keempat perlakuan adalah berbeda (3) Motivasi berwirausaha di perlakuan A adalah paling tinggi dan berbeda signifikan dengan perlakuan lainnya (4) Motivasi berwirausaha di perlakuan B adalah lebih tinggi dari perlakuan A dan berbeda signifikan dengan perlakuan lainnya (5) Motivasi berwirausaha di perlakuan $\mathrm{C}$ adalah lebih tinggi dari perlakuan B dan berbeda tidak signifikan dengan perlakuan D.

Hasil ANOVA pada mahasiswa dengan faktor penarik tinggi ini memberikan kesimpulan bahwa perlakuan $\mathrm{C}$ atau $\mathrm{D}$ adalah terbaik untuk meningkatkan motivasi berwirausaha.

\section{Pembahasan}

Berdasarkan hasil pengujian hipotesis di atas menunjukkan bahwa ada perbedaan yang signifikan motivasi kewirausahaan antara kelompok mahasiswa yang dikenai strategi pembelajaran kewirausahaan (perlakuan) dan kelompok kontrol. Pada kelompok perlakuan, mahasiswa memperoleh skor rerata motivasi kewirausahaan yang lebih tinggi dibandingkan mahasiswa di kelompok kontrol. Hal ini berarti bahwa penerapan strategi pembelajaran kewirausahaan terbukti memiliki potensi memberikan pengaruh lebih baik terhadap motivasi kewirausahaan.

Temuan penelitian ini sejalan dengan temuan-temuan penelitian yang dilakukan sebelumnya antara lain adalah hasil penelitian Naomi (2000), Fregetto, E. (2002), Hickcox (1991), Iliff (1994), Kolb, Boyatzis\& Mainemelis (2001), Lepoutre et. al, 2005, Naomi (2000), Ahmad et. Al (2010), Pihie (2009), Schreier (1984), Douglas \& Shepherd (2002), Rasmussena dan Sørheimb (2006), Atherton (2007), Gorman\& Hanlon ( 1997), Mcmullan\& Gillin (1998) dan Vesper (1994) yang menemukan bahwa kewirausahaan dapat diajar sehingga mahasiswa akan memperoleh pengalaman, kepercayaan dan pengetahuan terhadap suatu bisnis atau menggunakan pengalaman baru yang mereka berhasil temukan untuk memulai usaha sebagai pilihan karir setelah meraka lulus.

Pada kelompok mahasiswa yang sama sekali tidak mendapatkan materi kuliah kewirausahaan memiliki motivasi berkarir menjadi wirausahawan paling tinggi dibandingkan dengan empat kelompok perlakuan lainnya. Sedangkan pada 
kelompok perlakuan, motivasi berkarir menjadi wirausahawan pada perlakuan pemberian teori kewirausahaan ditambah penugasan dan pemutaran video tokoh success berwirausaha adalah lebih tinggi daripada pemberian teori kewirausahaan ditambah penugasan dan cerita tokoh sukses berwirausaha, akan tetapi tidak berbeda dengan pemberian teori kewirausahaan ditambah penugasan dan brainstorming berbagai pemikiran berkarir menjadi wirausaha.

Berdasarkan kajian tentang kewirausahaa dan model-model pembelajaran maka dilakukan penerapan model pembelajaran yang memiliki sintak sederhana yaitu (1) pemberian tugas dan penyelesaian tugas serta (2) menganalisis tugas dan refleksi. Sintak ini dipilih karena sesuai kondisi subyek yaitu mahasiswa di semester 3 atau lebih, dibatasi waktu, model praktis dilaksanakan, yaitu pembelajaran kewirausahaan akan lebih berhasil apabila pelibatan mahasiswa dimaksimalkan, dosen lebih memerankan diri sebagai fasilitator dengan mengaktifkan peserta dalam diskusi, presentasi dan kerja kelompok. Pemilihan strategi pemberian tugas yang disesuaikan dengan karakteristik mahasiswa ini bahwa untuk efektivitas penerapan model perlu disesuaikan dengan peserta.

Untuk lebih mengefektifkan penerapan model pembelajaran kewirausahaan maka dilengkapi dengan strategi-strategi pembelajaran lain seperti penayangan film dan video (audio visual), ceramah dengan media power poin, diskusi dan kerja kelompok. Pemanfaatan media audio-visual merupakan stimulan pembelajaran yang menarik perhatian peserta untuk melakukan tugas-tugas kelompok, diskusi dan refleksi diri. Pembelajaran kewirausahaan dengan beragam strategi memotivasi peserta lebih antusias dan bersemangat, aktivitas diskusi kelompok, presentasi kelompok dan debat dapat melengkapi model yang digunakan.

Aktivitas pelatihan dengan bantuan tayangan film dapat memberikan pengalaman baru, mempertahankan semangat dan keterlibatan peserta dalam proses pelatihan. Penggunaan potongan film atau video dapat: a) membantu mengembangkan pemahaman individu mengenai tema-tema kewirausahaan, b) meningkatkan kesadaran mengenai kesuskesan pada berbagai kewirausahaan, c) meningkatkan kesadaran tatapandang individu akan kewirausahaan sendiri dan semakin dapat memahami kewirausahaan. Pemilihan film dan video sebagai media 
pembelajaran agar dalam pembelajaran kewirausahaan, dosen menggunakan beragam metode pelatihan dengan ditambah pemanfaatan media film yang sesuai tema pembelajaran.

Pembelajaran kewirausahaan ini memanfaatkan bahan bacaan untuk melengkapi strategi ceramah yang cenderung bersifat satu arah. Stimulan pembelajaran kewirausahaan berupa bacaan diberikan kepada setiap peserta dilengkapi dengan lembar kerja sebagai perangkat pembelajaran kewirausahaan dan media melakukan refleksi. Bahan bacaan bermanfaat sebagai panduan pengembangan motivasi kewirausahaan.

Pemanfaatan film dan video lebih diminati peserta dibandingkan kegiatan pemberian teori dan tugas yang memerlukan berfikir lebih serius. Pesan yang disampaikan melalui film yang bersifat succes story lebih mudah dicerna dan dinikmati mahasiswa, perhatian peserta pada saat penyajian topik pembelajaran kewirausahaan menggunakan pemberian tugas, penayangan film dan brain strorming terasa berbeda. Fenomena ini mengindikasikan bahwa budaya menonton film sangat dominan dibandingkan dengan membaca. Namun untuk pengembangan aspek kognitif dan penguasaan konsep-konsep tentu tidak cukup hanya dengan tayangan film perlu dipadukan dengan pemberian tugas.

Kegiatan utama dari penerapan model pembelajaran kewirausahaan adalah memberikan tugas kepada peserta dan penyelesaian tugas, dalam setiap sesi dan selanjutnya dilakukan diskusi untuk penyelesaian tugas-tugas pembelajaran kewirausahaan. Pemberian tugas kelompok dengan melakukan diskusi dan presentasi ternyata cukup efektif dalam mengaktifkan peserta, hal ini bertujuan memberi kesempatan kepada peserta untuk mengeksplorasi dan mengutarakan pengalaman-nya untuk menemukan kesimpulan-kesimpulan baru. Presentasi hasil kerja kelompok juga sebagai media tukar menukar informasi dan pengetahuan dengan kelompok lain.

Pembelajaran kewirausahaan diawali dengan ekspositori (ceramah) untuk penyampaian materi-materi kunci sebelum pemberian tugas-tugas. Dosen menggunakan ekspositori pada awal sesi kegiatan sebagaimana teori perilaku verbal dalam pembelajaran kewirausahaan yang menerapkan tahapan: structuring, 
soliciting, reacting dan responding (Bellack, 1966). Perilaku structuring digunakan dosen untuk mengarahkan proses pembelajaran kewirausahaan agar dapat mencapai tujuan pembelajaran kewirausahaan, kemudian menanyakan lebih lanjut (soliciting) pemahaman peserta terhadap konsep-konsep yang dijelaskan, dan selanjutnya responding berupa komentar atau jawaban dari peserta serta pengerjaan lembar kerja oleh peserta dengan mendapatkan reacting dari dosen. Penyajian materi melalui ekspositori dengan menggunakan media power point cukup efektif untuk menjelaskan konsep-konsep kewirausahaan, pemanfaatan media visual sebagaimana dinyatakan Abdelraheem (2005) sangat diperlukan untuk mendukung efektivitas pembelajaran kewirausahaan di bidang ilmu-ilmu sosial agar proses pemahaman konsep-konsep yang abstrak lebih mudah dijelaskan.

Sintak kedua model pembelajaran kewirausahaan adalah pembahasan tugas dengan melakukan diskusi kelompok, presentasi, curah pendapat dan tanya jawab. Pada pembahasan (langkah kedua) dilanjutkan dengan refleksi yang menjadi bagian penting dalam setiap sesi pembelajaran kewirausahaan untuk melakukan refleksi pengalaman belajarnya. Refleksi dilakukan untuk melihat setiap proses perkembangan perilaku yang harus mereka kuasai, hal ini sesuai pendapat Remer (2007) bahwa merefleksi diri akan membuka mata hati dan pikiran peserta dalam menilai segala tindakannya yang mungkin tidak produktif dan menemukan sejumlah kekeliruan yang perlu diperbaiki. Peserta yang melakukan refleksi akan mengetahui capaian belajar mereka dan berusaha memaksimalkan capaian tersebut. Refleksi dalam pembelajaran kewirausahaan ini dilakukan saat pembelajaran kewirausahaan berlangsung, mencakup refleksi terhadap proses-proses pembelajaran kewirausahaan, manfaat pembelajaran kewirausahaan, perubahanperubahan kompetensi yang telah terjadi pada aspek kesadaran dan pengetahuan kewirausahaan. Refleksi peserta menyatakan, pembelajaran kewirausahaan cukup bermanfaat dan relevan dengan kebutuhan mahasiswa saat ini.

Penerapan model pembelajaran kewirausahaan yang inovatif dengan penambahan cerita tokoh sukses berwirausaha, penayangan video atau brainstorming didukung suasana pembelajaran kewirausahaan yang nyaman, komunkatif dan dialogis sangat diharapkan oleh peserta, karena dapat 
meningkatkan antusias dalam belajar. Suasana yang kaku dan monolog dapat menghambat terbentuknya kenyamanan belajar, oleh karena itu dalam penerapan model pembelajaran kewirausahaan dilakukan dengan menciptakan suasana nyaman. Rasa nyaman dalam proses pembelajaran kewirausahaan sangat dibutuhkan agar efektivitas pembelajaran kewirausahaan dapat tercapai. Pengelolaan pembelajaran kewirausahaan yang nyaman akan mengurangi tekanan belajar. Upaya menciptakan kenyamanan belajar dilakukan dengan pemberian cerita tokoh sukses berwirausaha, penayangan video atau brainstorming yang disesuaikan dengan topik pembelajaran kewirausahaan. Sikap proaktif terhadap pembelajaran kewirausahaan muncul karena peserta merasakan kenyamanan dalam pembelajaran kewirausahaan.

Pemberian penghargaan terhadap peserta dan kelompok yang dapat menyelesaikan tugas pembelajaran kewirausahaan terbukti efektif untuk mempertahankan semangat belajar, peserta bersemangat dan berkompetisi ketika mengerjakan tugas-tugas. Penghargaan dan refleksi yang dilakukan sebagai bentuk pemberian penguatan terhadap proses dan hasil pembelajaran kewirausahaan, hal ini sesuai pendapat Simamora (2004) tentang perlunya penguatan dalam pembelajaran kewirausahaan. Refleksi peserta menunjukkan adanya penilaian diri terhadap kompetensi dan menyadari adanya kekurangan pada konseling yang dilakukan.

Beberapa studi literatur kualitatif dan kuantitatif banyak menemukan efektivitas experiential learning dalam berbagai situasi, dan telah terbukti dapat digunakan sebagai kerangka untuk pengembangan metoda dan kurikulum learningcentred yang baru (Hickcox, 1991; Iliff, 1994). Experiential learning telah digunakan dalam inter-disciplinary dan multi-disciplinary (Kolb, Boyatzis\& Mainemelis, 2001). Experiential learning sebagai alat penghubung pendidikan dan manajemen.

Teknik pembelajaran experiential adalah teknik yang modifikasi format kualiah melalui ceramah sebagai metode tradisional dengan siswa bekerja melalui pengalaman yang tersusun dalam kelompok kecil (Gaidis, Andrews, \& summer, 
1991) untuk melaksanakan riset pemasaran nyata (Churchill, 1986) sebelum magang full-time sebagai praktek usahawan (Aronsson, 2004).

Beberapa studi empiris menemukan hal positif bahwa kewirausahaan dapat diajarkan melakukan literatur review beberapa penelitian dalam jangka waktu 10tahun berkaitan dengan pendidikan kewirausahaan dan menemukan bahwa sebagian besar dari studi empiris yang disurvei menemukan kewirausahaan dapat diajarkan melalui pendidikan kewirausahaan.

Wang \& Wong (2004) dalam penelitian di Singapura, menemukan bahwa sebelum mengenal pendidikan kewirausahaan, mahasiswa mempunyai persepsi dan pengetahuan yang tinggi tentang kewirausahaan. Setelah mengambil matakuliah kewirausahaan persepsi mahasiswa mengalami peningkatan. Lee\& Wong ( 2003) dalam studinya menemukan bahwa pendidikan kewirausahaan pada perguruan tinggi mempunyai hubungan langsung dalam membentuk sikap siswa dalam mengambil resiko untuk pendirian usaha baru. Penelitian Lee \& Wong menduga bahwa persepsi usahawan semakin positif melalui pendidikan kewirausahaan, namun juga dipengaruhi oleh faktor lingkungan eksternal dan dukungan kewirausahaan oleh pemerintah. Lebih dari itu, pemerintah Singapura banyak melakukan dukungan agar mahasiswa setelah lulus dapat memulai usaha baru.

Menurut Solomon dan Fernald (1991) serta Hisrich dan Peters (2002) sebagaimana dikutip Bell (2008), pendidikan kewirausahaan tradisional memfokuskan pada penyusunan rencana bisnis, bagaimana mendapatkan pembiayaan, proses pengembangan usaha dan manajemen usaha kecil. Pendidikan tersebut juga memberikan pengetahuan mengenai prinsip-prinsip kewirausahaan dan keterampilan teknis bagaimana menjalankan bisnis. Namun demikian, peserta didik yang mengetahui prinsip-prinsip kewirausahaan dan pengelolaan bisnis tersebut belum tentu menjadi wirausaha yang sukses (Solomon and Fernald dalam Bell, 2008).

Mereka perlu dibekali dengan berbagai atribut, keterampilan dan perilaku yang dapat meningkatkan kemampuan kewirausahaan mereka. Artinya mata kuliah kewirausahaan perlu dirancang secara khusus untuk dapat mengembangkan karakteristik kewirausahaan, seperti kreativitas, pengambilan 
keputusan, kepemimpinan, jejaring sosial, manajemen waktu, kerjasama tim, dll (Brockhaus; Rae, dalam Bell, 2008). Untuk itu diperlukan perubahan sistem pendidikan kewirausahaan yang tadinya difokuskan pada orientasi pengendalian fungsional seperti, keuangan, pemasaran, sumber daya manusia dan operasi (Meyer dalam Bell, 2008) menjadi fokus pada mengembangkan jiwa kewirausahaan pada peserta didik. Sehingga tantangannya adalah bagaimana sistem pembelajaran yang dapat mengembangkan diri peserta didik mereka dalam hal keterampilan, atribut dan sekaligus karakteristik perilaku seorang wirausaha (Gibb, dalam Bell, 2008).

Merujuk pada asumsi diatas, maka Experiential Learning sebagai sebuah metode pembelajaran, adalah proses menjalani pengalaman yang diciptakan secara sengaja agar terdapat peluang untuk terjadi proses belajar yang diinginkan. Pengalaman terstruktur seperti ini dibutuhkan untuk menyediakan kerangka terjadinya proses induktif seperti diagram diatas, yaitu mulai dari: (a) Concrete Experience (CE), yaitu ketika peserta melakukan aktivitas melalui beragam game/simulasi yang telah dirancang sebelumnya, (b) Observation \& Reflection $(O R)$, ketika peserta di fasilitasi untuk menguraikan kembali mengenai apa yang sebenarnya terjadi pada dirinya/ kelompok dan mengapa hal tersebut bisa terjadi, (c) Abstract Conceptualization (AC), yaitu ketika berdasarkan hasil OR, para peserta mencoba melakukan generalisasi tentang pengalaman tersebut dan lmenjadikannya lesson learned untuk dijadikan pedoman untuk kejadian yang setara di kemudian hari; dan dalam hal ini diperlukan lecturing teori teori yang mendasari generalisasi tersebut oleh fasilitator, (d) Active Experimentation (AE), yaitu ketika berdasarkan hasil generalisasi peserta mencoba untuk mengujinya pada kondisi yang sebenarnya; dan dalam konteks pembelajaran, bisa di simulasikan melalui assignment, disertai review dan coaching oleh fasilitator. Experiential Learning sangat efektif untuk pemahaman skill yang bersifat professional competence dari dunia kerja seperti: leadership, communication, creativity, conflict handling, dan termasuk didalamnya teamworking skill.

Hasil penelitian ini mendukung teori-teori sebelumnya, bahwa pembelajaran kewirausahaan dapat diterapkan untuk meningkatkan motivasi untuk berkarir 
menjadi wirausahawan. Keberhasilan penerapan model pelatihan juga ditentukan oleh pemilihan model pembelajaran yang disesuaikan dengan karakteristik dan kondisi peserta. Sintak pembelajaran yang mudah dilaksanakan.

Hasil penelitian ini menunjukkan bahwa ada perbedaan pola peningkatan motivasi kewirausahaan antara kelompok mahasiswa yang memiliki faktor penarik tinggi dan kelompok mahasiswa yang memiliki faktor penarik tinggi. Kelompok mahasiswa yang memiliki tingkat faktor penarik tinggi memperoleh motivasi kewirausahaan yang lebih baik daripada mahasiswa dengan faktor penarik tinggi. Hal tersebut dapat diartikan bahwa faktor penarik terbukti memiliki pengaruh terhadap motivasi kewirausahaan.

Hasil temuan ini mendukung hasil penelitian sebelumnya yang dilakukan oleh Lee dan Wong (2003), bahwa faktor penarik berpengaruh dalam meningkatan motivasi kewirausahaan. Faktor lingkungan dilihat dari faktor dalam aspek demografis (umur, gender, pendapatan, pendidikan) dan psikologis (need for achievment, locus of control, pengambilan resiko dan kebebasan). Sebaliknya, "pull" theory berpendapat bahwa individu untuk menjadi wirausaha karena memang mencari hal-hal berkaitan dengan karakteristik wirausaha itu sendiri, seperti kemandirian atau memang karena yakin berwirausaha dapat memberikan kemakmuran. Beberapa penelitian (Keeble et al., 1992; Orhan and Scott, 2001) mengindikasi bahwa kebanyakan individu menjadi wirausaha terutama disebabkan “pull” factors, daripada "pushl” factors.

Namun beberapa studi lain menemukan bahwa kewirausahaan tidak mudah diajarkan (seperti dilakukan oleh: Audet. 2004; Shen dan Chai, 2006; Lekhotla, 2007; Lee dan Wong, 2003; Verheul, 2001; Brazeal et. al, 2008). Hal tersebut disebabkan karena dampak pembelajaran kewirausahaan seperti melalui Kewirausahaan (experiental) terhadap niat untuk berwirausaha sebagai pilihan karir tidak dapat diukur hanya melalui persepsi jangka pendek tetapi dalam periode lama dan fluktuatif (Audet. 2004), disamping itu pembelajaran kewirausahaan perlu dukungan faktor penarik (opportunity) seperti peluang pasar dan dukungan pemerintah (Shen dan Chai, 2006; Lekhotla, 2007; Lee dan Wong, 2003; Verheul, 2001; Brazeal et. al, 2008). 
Dalam rangka mengembangkan ketrampilan wirausahawan, perilaku dan pengetahuan (Garavan dan Barra, 1994) penekanan diperlukan dalam menyusun metode pembelajaran (Gibbs, 1988), atau pembelajaran berbasis pengalaman/ experiential learning ( Kolb, 1984). Pendekatan ini adalah juga mendapat dukungan dalam literatur kewirausahaan, yang menyatakan bahwa tindakan wirausahawan cenderung berorientasi berdasarkan pada pengalaman mereka (Rae dan Carswell, 2000).

\section{Kesimpulan}

Berdasarkan pada hasil dan pembahasan penelitian bahwa metode pembelajaran kewirausahaan berpengaruh untuk meningkatkan motivasi untuk berkarir menjadi wirausahawan, dapat ditarik beberapa simpulan pokok sebagai berikut.

\begin{tabular}{|l|c|c|c|c|c|c|}
\hline Perlakuan & Rata-rata & \multicolumn{5}{|c|}{$p$-value hasil uji beda } \\
\cline { 3 - 7 } & & Kontrol & A & B & C & D \\
\hline Kontrol & $140.726^{\mathrm{a}}$ & - & $0.847 \mathrm{~ns}$ & $0.258 \mathrm{~ns}$ & $0.005^{*}$ & $0.000^{*}$ \\
$\mathrm{~A}$ & $141.783^{\mathrm{a}}$ & $0.847 \mathrm{~ns}$ & - & $0.435 \mathrm{~ns}$ & $0.029 \mathrm{~ns}$ & $0.004^{*}$ \\
$\mathrm{~B}$ & $146.443^{\mathrm{a}}$ & $0.258 \mathrm{~ns}$ & $0.435 \mathrm{~ns}$ & - & $0.098 \mathrm{~ns}$ & $0.030^{*}$ \\
$\mathrm{C}$ & $154.345^{\mathrm{a}}$ & $0.005^{*}$ & $0.029^{*}$ & $0.098 \mathrm{~ns}$ & - & $0.488 \mathrm{~ns}$ \\
$\mathrm{D}$ & $157.728^{\mathrm{a}}$ & $0.000^{*}$ & $0.004^{*}$ & $0.030^{*}$ & 0.488 & - \\
\hline
\end{tabular}

(1). Pemberian materi kuliah kewirausahaan dapat meningkatkan motivasi berwirausaha (2) Motivasi berwirausaha pada mahasiswa dari keempat perlakuan (kelompok A, B, C dan D) adalah berbeda

(3) Perubahan motivasi berwirausaha di perlakuan B tidak berbeda signifikan $(\mathrm{p}=0.435$ ) dibandingkan dengan kelompok perlakuan A. (4) Perubahan motivasi berwirausaha di perlakuan $\mathrm{C}$ berbeda tidak signifikan $(\mathrm{p}=0.029)$ dibandingkan dengan kelompok perlakuan A. (5) Perubahan motivasi berwirausaha di perlakuan D berbeda signifikan ( $\mathrm{p}=0.004$ ) dibandingkan dengan kelompok perlakuan A. (6) Perubahan motivasi berwirausaha di perlakuan $\mathrm{C}$ adalah tidak berbeda signifikan ( $\mathrm{p}=0.098)$ dibandingkan dengan perlakuan B (7) Perubahan motivasi berwirausaha di perlakuan $\mathrm{D}$ adalah berbeda signifikan $(\mathrm{p}=0.030)$ dibandingkan dengan 
perlakuan B (8) Perubahan motivasi berwirausaha di perlakuan D adalah tidak berbeda signifikan $(\mathrm{p}=0.488)$ dibandingkan dengan perlakuan $\mathrm{C}$.

Akhirnya bisa dikatakan bahwa metode pembelajaran yang diterapkan bisa merubah motivasi mahasiswa berwirausaha antara lain: (1) Pembelajaran kewirausahaan dengan meode A, B, C dan D berpengaruh signifikan terhadap perubahan motivasi berwirausaha mahasiswa dengan factor penarik tinggi. (2) Metode pembelajaran Brainstorming memberikan perubahan motivasi mahasiswa berwirausaha tertinggi (3) Metode pembelajaran menonton video tokoh sukses berwirausaha memberikan perubahan motivasi mahasiswa berwirausaha tertinggi kedua.

\section{DAFTAR PUSTAKA}

Cope, J. (2005), Towards a dynamic learning perspective of Entrepreneurship, Entrepreneurship: Theory and Practice, Vol. 29 (4), pp. 373-397.

Coulter, M. 2003. Entrepreneurship in Action. New Yersey: Prentice Hall DP2M Ditjen Dikti. (2006). Panduan Pengelolaan Program Hibah DP2M Ditjen Pendidikan Tinggi. Jakarta: Direktorat Penelitian dan Pengabdian. kepada Masyarakat Direktorat Jenderal Pendidikan Tinggi

Edwards, A.L. (1957). Techniques of Attitude Scale Construction. New York: Appleton Century Croft Inc.

Ferreira, J.J. and Raposo, M.L. (2008), Entrepreneurial Intention: a cara with psychological and behavioural approaches, Conference Proceedings, 31st Institute for Small Business and Entrepreneurship Conference on International Entrepreneurship, 5-7 November, 2008, Belfast.

Fregetto, E. 2002. Business Plan Or Business Simulation For Entrepreneurship Education?. Developments in Business Simulation and Experiential Learning, Volume 29.

Galloway,L \& Brown, W. 2002. Entrepreneurship Education at University: A Driver in The Creation of High Growth Firm?. Education \& Training Journal, Vol. 44, Iss. 8/9, pg. 398, 8 .

Gilad,B.andLevine,P.(1986),A behavioral cara of entrepreneurial supply , Journal 
of Small Business Management,Vol.24 No.4, pp.45-54.

Hostager, T. J., \& Decker, R. L. (1999). The effects of an entrepreneurship program on achievement motivation: A preliminary study. San Francisco: SBIDA. http://kamusbahasaindonesia.org/wirausaha, diambil pada tg 26 Maret 2011 jam 9.06 WIB

Kolb, D. A., (1984), Experiential learning - Experience as the source of learning and development, London: Prentice-Hall.

Krueger, J., Norris F. (2000). The Cognitive Infrastructure of Opportunity Emergence. Entrepreneurship: Theory \& Practice, 24(3), 5-23.

Kuratko, D. F. (2005). The Emergence of Entrepreneurship Education: Development, Trends, and Challenges. Entrepreneurship: Theory \& Practice, 29(5), 577-597.

Lambing \& Kuehl (2003) Cultural Dimension at the Individual Level of Analysis the Cultural Orientation Framework, International Journal of Cultural Management,2(3):275-296.

Lambing, P. A. \& Kuehl, C. R. 2003. Entrepreneurship. New Yersey: Prentice Hall....

Lee, L., \& Wong, P.-K. (2003). Attitude towards Entrepreneurship Education and New Venture Creation. Journal of Enterprising Culture, 11(4), 339-357.

Léonie L. Stone, Multimedia Instruction Methods, JOURNAL OF ECONOMIC EDUCATION, is an assistant professor of economics at SUNY at Geneseo (e-mail: stone@uno.cc.

Marvel, M.R. and Lumpkin, G.T. (2007), Technology entrepreneurs human capital and its effects on innovation radicalness, Entrepreneurship: Theory and Practice, Vol. 31(6), pp.807-827.

Naomi, R. W. H. 2000. Evaluating the impact of SPEED on students' career choices: a pilot study. Education Training Vol. 52 Nos. 6/7, 2010 pp. 463 476. Emerald Group Publishing Limited

Nasution, Noehi. 1992. Psikologi Pendidikan. Jakarta: Depdikbud, Ditjen Dikti. 
Pihie, Z. A.L. 2009. Entrepreneurship as a Career Choice: An Analysis of Entrepreneurial Self-Efficacy and Intention of University Students. European Journal of Social Sciences - Volume 9, Number 2 (2009)

Priyanto, Sony Heru. 2002. Pengembangan Kapasitas Manajemen dan Kewirausahaan pada UKM Pertanian. Jurnal Ekonomi dan Bisnis, Vol. VIII, No. 3, 401-424.

Rae, D \& Carswell, M. 2000. Using a Life Story Approach in ResearchingEntrepreneurial Learning: The Development of a Conceptual Model and its Implications in The Design of Learning Experiences. Education \& Training Journal, Vol. 42. Iss. 4/5, pg. 220, 8 pgs.

Rae, D., and Carswell, M. (2000), Using a life-story approach in researching entrepreneurial learning: The development of a conceptual cara and its implications in the design of learning experiences, Education and Training, 42(4/5), 220-227.

Raichaudhuri, A. (2005). Issues in Entrepreneurship Education. Decision, 32(2), 73-84.

Rasmussena, E. A. dan Sørheimb,R. 2006. Action-based entrepreneurship education. Technovation 26 (2006) 185-194

Remer, B. (2007). Reflective Practice: Learning from Real-world Experience. In M. Silberman, The Handbook of Experiential Learning. San Fransisco: John Wiley \&Sons, Inc.

Segal, Gerry, Borgia, Dan and Jerry Schoenfeld, (2005):The motivation to become an entrepreneur, International Journal of Entrepreneurial Behaviour \&Research, Vol. 11 No. 1, 2005 pp. 42-57

Setyosari, Punaji, Sihkabuden. 2005. multimedia Pembelajaran. Malang : Elang Press

Shadish, W.R., Cook, T.D. \& Campbell, D.T. (2002). Experimental and QuasiExperimental Designs for Generalized Causal Inference. New York: Houghton Mifflin Company.

Shen, C dan Chai, L. 2006. Changing Entrepreneurial Perceptions and Developing Entrepreneurial Competencies through Experiential Learning: Evidence 
From Entrepreneurship Education in Singapore's Tertiary Education Institutions. Journal of Asia Entrepreneurship and Sustainability Volume II, Issue 2, 2006

Suharsono, Naswan. 2003. Pola Kuliah Kewirausahaan di LPTK. Makalah disampaikan dalam Seminar Nasional Pengembangan . Budaya Wirausaha di Perguruan Tinggi. Jakarta: Direktorat Pembinaan Penelitian dan Pengabdian pada Pada Masyarakat. Dirjen Pendidikan Tinggi, 9-10 Mei 2003

Sutikno, M. Sobry, (2009) Belajar dan Pembelajaran "Upaya kreatif dalam mewujudkan pembelajaran yang berhasil"; Cetakan ke lima September 2009, Prospect, Bandung.

Tan, S.S. and Ng, C.K.F. (2006), A problem-based learning approach to entrepreneurship education, Education and Training, Vol. 48(6), pp.416428.

Vinsky, J. (2006). Transformative Video Therapy (TVT): Using Technology to Create Pathways to a "Witness Consciousness". Project Paper for the Hinks-Dellecrest "Breaf and Narrative Therapy Year-Loang Training Programme. Toronto Canada.

Wang, C. K., \& Wong, P.-K. (2004). Entrepreneurial interest of university students in Singapore. Technovation, 24(2), 163-172.

Wiedy Murtini. 2004. Pendidikan Kewirausahaan di Perguruan Tinggi: Sebuah Gagasan Pemodelan Wirausaha Kecil dan Menengah Sukses. Forum Pendidikan, Vol. 29, No. 02, Agustus 2004, 141-155.

Wiedy Murtini. 2007. Pengembangan desaín pembelajaran pendidikan kewirausahaan dengan pemodelan wirausahawan UKM sukses, (desertasi tidak untuk dipublikasikan). 2007, 221-222.

Wirausaha \& Keuangan. 2008. Seandainya dosenku seperti Profesor Bob Sadino. Jakarta:WK. Edisi 62, Juni 2008, 4-5

Young, J. E., and Sexton, D. L. (1997), Entrepreneurial learning: A conceptual Framework, Journal of Enterprising Culture, 5(3), 223-248.

Zimmerer \& Scarborough (1998) Essentials of Entrepreneurship and Small 
Relasi : Jurnal Ekonomi, Vol. 17, No. 1, Januari 2021, hlm. 1-32

Business Management. Second Ed. Prentice Hall. 